\title{
Correction to: Exponential Moments for Planar Tessellations
}

\author{
Benedikt Jahnel ${ }^{1} \cdot$ András Tóbiás $^{2}$
}

Published online: 7 April 2021

(C) The Author(s) 2021

\section{Correction to: Journal of Statistical Physics (2020) 179:90-109 https://doi.org/10.1007/s10955-020-02521-3}

The article Exponential Moments for Planar Tessellations, written by Benedikt Jahnel and András Tóbiás was originally published electronically on the publisher's internet portal on 16th March 2020 without open access. With the author(s)' decision to opt for Open Choice the copyright of the article changed on 5th March 2021 to (C) The Author's 2021 and the article is forthwith distributed under a Creative Commons Attribution.

The original article has been corrected.

Open Access This article is licensed under a Creative Commons Attribution 4.0 International License, which permits use, sharing, adaptation, distribution and reproduction in any medium or format, as long as you give appropriate credit to the original author(s) and the source, provide a link to the Creative Commons licence, and indicate if changes were made. The images or other third-party material in this article are included in the article's Creative Commons licence, unless indicated otherwise in a credit line to the material. If material is not included in the article's Creative Commons licence and your intended use is not permitted by statutory regulation or exceeds the permitted use, you will need to obtain permission directly from the copyright holder. To view a copy of this licence, visit http:// creativecommons.org/licenses/by/4.0/.

Publisher's Note Springer Nature remains neutral with regard to jurisdictional claims in published maps andinstitutional affiliations.

The original article can be found online at https://doi.org/10.1007/s10955-020-02521-3.

Benedikt Jahnel

benedikt.jahnel@wias-berlin.de

András Tóbiás

tobias@math.tu-berlin.de

1 Weierstrass Institute for Applied Analysis and Stochastics, Mohrenstraße 39, 10117 Berlin, Germany

2 TU Berlin, Berlin Mathematical School, Straße des 17. Juni 136, 10623 Berlin, Germany 